\title{
Rescuing Rationality from the Rationalists: For a Neo-Weberian Understanding of Rationality in Critical Terrorism Studies ${ }^{4}$
}

\section{Bernardino Leon-Reyes}

\author{
https://doi.org/10.22151/politikon.41.3
}

Bernardino Leon-Reyes, 22, from Málaga (Spain), is currently a La Caixa Scholar' and a Master's student in Anthropology of 'Politics, Violence and Crime', at University College London's Department of Anthropology. Prior to this, he completed his Bachelor's degree in Sociology and Philosophy at the Université Paris Sorbonne (Paris-IV), and his Master's degree in 'International Relations Theory' at the London School of Economic and Political Science (LSE), where he wrote his dissertation on the power-knowledge nexus of (neo)liberal Conflict Studies. He bas worked as a member of Millennium - Journal of International Studies' Editorial Board (Vol. 47 No. 1), and he currently serves as Commissioning Editor at E-IR. His interests include International Political Sociology, Critical Terrorism Studies, the anthropology of revolutions, and post-structural IR Theory. E-mail bernardino.leon.reyes@gmail.com.

\begin{abstract}
A decade after its emergence, Critical Terrorism Studies (CTS) has remained unable to engage with one of the most prominent discourses that, on the one hand, justifies the debumanisation of those accused of terrorism and, on the other, disciplines critical scholarship: the presentation of the terrorist as an irrational subject. Recognising the tensions that emerge from CTS's critical understanding of "the world" and its simultaneous aim of making knowledge claims, this paper draws on the work of Max Weber in order to create a reflexive methodology able to analyse the rationality of terrorism. After showing the incompatibility between recent understandings of rationality in 'mainstream' terrorism studies with CTS, and the limits of 'postmodern' stances, this article proposes a neo-Weberian 'via media' capable of offering an analysis of the rationalities of terrorism, while remaining sensitive to the limitations of social theory.
\end{abstract}

\section{Keywords}

Critical Terrorism Studies; Ideal-type; International Relations Theory; International Sociology; ISIS; Max Weber; Methodology; Rationality; Social Action

\footnotetext{
${ }^{4}$ This work was supported by "La Caixa” Fellowship [grant number LCF/BQ/EU18/11650025].
} 


\section{Introduction}

Why is it relevant for Critical Terrorism Studies (CTS) to elucidate whether terrorism is rational or not? After all, CTS was articulated as a "critique of the existing field" (Jackson et al., 2009: 216-7) in an effort "to highlight a number of potentially serious problems" that have characterised the conduct of inquiry in orthodox terrorism studies (Jarvis, 2016: 61). CTS scholars have been, consequently, more interested in exposing dubious epistemological, ontological and normative assumptions present in orthodox terrorism studies, rather than in engaging with definitional debates such as what rationality is. In this paper, nonetheless, I will suggest that determining whether terrorism is rational has both important theoretical and practical implications that, indeed, CTS should take into account.

This paper will argue that CTS should adopt a Weberian ideal-typical approach to rationality. Section one will present why CTS should adopt the methodological tool of the ideal-type. I will start by showing why the question of rationality is relevant for CTS, followed by the shortcomings and epistemological incompatibilities of the dominant understandings of rationality in terrorism studies. I will commence this section arguing how an ideal-type of rationality offers a potential solution, as a "via media" between "rationalist" and "particularist" approaches. Furthermore, in section two, I will argue why Max Weber's typification of rationality represents a useful point of departure to conceptualise this ideal-type, explaining his model of rationalities, and sketching some of the ways in which it could be applied to the study of terrorism. Rather than a case study, this paper is a proposal for this specific approach, and an invitation for further research.

\section{The Case for an Ideal-Typical Approach to Rationality in CTS The Relevance of the Question of Rationality}

The notion that terrorism is irrational has not only precluded a rigorous study of terrorism; it has also led to the "villainisation and demonisation of researchers as 'sympathisers' and 'defenders' of terrorists" (Stampnitzky in Tellidis, 2016: 627) when scholars have tried to study the motivations behind the actions of militants. This is what Lisa Stampnitzky (2013:189) refers to as the politics of "anti-knowledge" present in the discipline; "as terrorism is understood to be irrational, the very possibility of understanding it can be called into question.". Challenging the assumption of irrationality can, as well, be part of "overcoming the Orientalist" bias present in the discipline (Gunning, 2009: 172) and the gendered representations of terrorists as irrational (see Gentry and Sjoberg, 2016), because it would attempt to understand the orientation of actors situating them in their particular within socio-political contexts (Tellidis and Toros, 2015: 3), such as one of poverty or oppression. In short, determining that terrorism is rational is important in theoretical terms insofar 
as it bestows terrorism the status of being an intelligible phenomenon, something that can be studied and understood.

Moreover, since the commitments of CTS are both analytical and normative (Jackson et al. 2009), there are a set of practical reasons that justify a defence of the engagement with rationality. When terrorism is posited as an irrational phenomenon, and terrorists as irrational subjects, then it is pointless to attempt to change the contexts that conditioned how they "came to be", as they would not have followed a rational course of action. For instance, voices that call for the ending of American Imperialism in the Middle East as a way to address the "roots" of terrorism can be decried as foolish, inasmuch as terrorism is posed as a product of an irrational hatred towards the West, Modernity, or Christianity — "our way of life". This allows relocating the origin of the terrorist's grudge from a contingent US foreign policy to a less flexible American culture. It follows that, since the US "cannot" give up on their culture, democracy, or wealth, all that is left is to repress and kill these terrorists (Mann, 2005: 162). However, the consequences of portraying "terrorists as irrational fanatics" (Wolfendale, 2016: 258) are not only related to the legitimisation of targeted killings, or even interventions, on the basis of counterterrorism; this portrayal has also transformed "economic, political, and social structures" (Wolfendale, 2016: 258), operating as a justification for situations of exception beyond the law (see, e.g., Agamben, 2005). In light of the practices enabled by the discourses of/on irrationality, part of the project of CTS should, therefore, be to advance the idea that terrorists are rational actors. Hence, the question becomes how.

\section{Rationality in Terrorism Studies}

Notwithstanding the dominance of everyday discourses that paint the terrorist as an irrational and pathological individual, a considerable body of literature on rationality has been published in "orthodox" terrorism studies. Robert Pape (2003: 355) has argued, in relation to the case of the Israeli occupation, that despite the high cost for the individual, suicide terrorism cannot be considered irrational, as it is an "effective" means for the advancement of political goals. In this vein, Rational Choice Theory (RCT) has also been applied to terrorism to explain, for instance, the presence of suicide terrorism as the consequence of individual choices driven by "future selfgratifying benefits" (Perry and Hasisi, 2015: 72), or the absence of suicide terrorism by the dearth of these rational motivations (see, e.g., Kalyvas and Sánchez-Cuenca, 2005). In other words, for this body of thought, rationality has to do exclusively with the means chosen and not with preferences (Gambetta, 2005: ix). Orthodox scholarship has been predominantly positivist, directed to formulate causal empirical generalisations built on "falsifiable hypotheses on the basis of more general theories, and collecting the evidence needed to evaluate those hypotheses" (King et al., 1994: 37) (for an early 
critique exploring the notion of the ideal-type as a reconciliation between objectivism and subjectivism, see Timothy McKeown’s [1999] excellent review of King et al.).

For instance, when Bryan Caplan (2006: 99) explains that terrorists "estimate the costs and benefits of irrationality without bias" and that, in equilibrium, "the choice to be irrational reflects a rational estimate of the price", a certain mind-world dualism underlines his research, as the researcher can know the world as it is. Or, in terrorism studies, the terrorist as (s)he is. The key problem with this approach is that because it holds terrorism as an "objectively knowable" phenomenon, it is incompatible with the reflexive standpoint that constitutes CTS (Fitzgerald, 2016: 115-129).

Furthermore, orthodox scholarship has inquired how rationality can help policy makers predict certain actions to eradicate terrorism, following a "prioritisation of policy-relevant knowledge as the basis of legitimate academic output on terrorism." (Fitzgerald, 2016: 121). Pape, for instance, raises a question in Dying to Win (2006) that illustrates this point: "can we find a lasting solution to suicide terrorism that does not compromise our core interest in maintaining access to one of the world's key oil-producing regions?” Following Robert Cox's (1981) distinction, orthodox terrorism studies are "problem-solving" theories that lack critical distance from governments (Fitzgerald, 2016: 121) working as patches to hegemonic relations of power. In contrast, CTS are critical because they call into question the origins and transformations of these social and power relations (Cox, 1981: 129). Therefore, the above-mentioned positivist epistemology, and this problem-solving use of RCT are at best scarcely compatible with the methodology of CTS — if not the very assumptions against which CTS emerged. Thus, if Hayward Alker (1990) called for rescuing reason from rationalists (understanding by rationalists positivists; what Robert Keohane [1988] labelled as such), in this paper I will attempt to rescue rationality from "rationalists".

However, what do we find on the other "extreme"? At the very heart of CTS, we find the post-structuralist approach to questions such as "what is rationality?". In an analogous fashion to the cartesian hyperbolic doubt-yet without the horizon of the determination of truth-poststructuralist authors leave aside the question of what rationality is, delving instead into the ways in which rationality is deployed in dominant discourses. For instance, Judith Butler considers rationality unstable, unfixed, and performative; in other words, everyday discourses creates and legitimates what rationality is. She analyses how the Western civilisational discourse sets Islamic beliefs and practices as "tokens of mental illness", in opposition to hegemonic norms of "Western rationality" (Butler, 2006: 72). Furthermore, others have focused on rationality as a teleological discourse of modernity grounded on a "forced and contingent" separation between nature/animal and human, in which essentially, they are dependent on each other. In both cases, nevertheless, a political investigation underwrites; namely how reason can legitimise the "rationalisation" of others, which in turn enables 
"going against their inner beings". Hence, in post-structuralism's ontology, there is no rationality outside discourse (cf. Dillet, 2017). In stark contrast with positivism, where a law-like "egoistic" rationalism is assumed to exist as an explanatory model for behaviour, the post-structuralist research programme is concerned with unveiling particular rationalities. In the words of Michel Foucault (1983: 210), "what we have to do is analyze specific rationalities rather than always invoke the progress of rationalization in general". This approach represents the danger that Richard Jackson et al., pioneers of CTS, warned against: "that critical scholarship, with its understandable concern for interrogating the discursive foundations upon which the study of terrorism is founded [...], disengages from the empirical study of political violence and its foundations in the 'real' world" (Jackson et al., 2009: 233).

CTS scholars have further options beyond the orthodox RCT rationality and the poststructuralist deconstruction of the concept. However, albeit "methodological and disciplinary pluralism" was characteristic of CTS (Jackson et al., 2009: 225-6), it has been the adherence to "postpositivist and non-international relations based methods and approaches" and the commitment to understanding (beyond "linear notions of cause and effect"), that has framed CTS's research agenda as sui generis (Jackson et al., 2009). Indeed, most CTS scholars have been committed either to a certain "analyticism" (following post-structuralism and historical sociology, ethnography, inter alia) or to "reflexivism" (following Critical Theory, feminism, and postcolonial scholarship) since the conditio sine qua non in CTS (cf. Stump, 2016: 218) has been scepticism over the ontological difference between "knowledge" and "world" (Jackson, 2010: 116). There is, therefore, a monist epistemology that underpins CTS. This epistemology is expressed in the maxim "terrorism does not exist outside of the definitions and practices that seek to enclose it" that cannot be "adequately defined due to its unstable ontological status" (Jackson, 2008: 28-9). This might uncover a tension in CTS: on the one hand, it holds that categories in/of the social world—be it terrorism or rationality—are ontologically unstable; yet, on the other hand, it attempts to demonstrate that, for instance, state terrorism is terrorism; namely to make "truth" claims.

Sociology, just as post-structuralism, feminism, Critical Theory, or post-colonial theory provides a reflexive approach (Smith, 2002: 227), which has yet to be fully explored in CTS. Besides "counter[ing] the ahistoricity and lack of context that terrorism research has often been accused of" (Gunning, 2009: 172), I suggest that sociology offers the resource of the ideal-type as a "via media" between the objectivist law-like claims of positivism and the particularist approach of many critical theories, including but not limited to the concept of rationality. The ideal-type itself was conceptualised by the sociologist Max Weber as a via media to the methodological debate (Methodenstreit) between the nomothetic Austrian School and idiographic German "Historicists" (Gerhardt, 1994: 78; Lebow, 2017: 43). Weber followed Simmel in the division between law-like 
sciences (Gesetzeswissenschaften) and what he called the cultural sciences (Kulturwissenschaften), where such regularities were impossible to find (Lebow, 2017: 51-53). However, he did seek a method to overcome the particularist intuitionism characteristic of historians "in an attempt to explain individual social phenomena as an outcome of historical process and also as a manifestation of wider institutional structural patterns" (Gerhardt, 1994: 78).

Hence, a possible route to overcome the above-mentioned impasse-without claiming to be the sole, nor the best one-is adopting an ideal-typical approach to the question of rationality. Similarly to what Jackson proposed in regard to the definitional deadlock (namely to "retain the term [of terrorism] as a focus for research [...] according to a set of identifiable and unique characteristics" in spite of its instability (Jackson, 2008: 29-31), an ideal-type is a mental construct that exaggerates certain aspects of a social phenomenon for analytical and pragmatic reasons. It is, at the same time, a simplification and a misrepresentation of reality that allows us to understand an object or a process (Jackson, 2010: 143). The ideal-type is an idealisation not in a normative way, but insofar it does not exist in the real world; it abstracts, combines, and exaggerates elements that are present in real phenomenon (Weber, 1978 [1922]: 20). The ideal-type provides "a schematic representation" of a social phenomenon that works as an "analytical grip" (Swedberg and Agevall, 2016: 156) to make knowledge claims without engaging in objectivism (Lebow, 2017: 70-71). An ideal-type is "used" (see Swedberg, 2018; Gerhardt, 1994) by confronting it to the individual empirical cases and observing the correspondence or contrasts in it, analogous to the outline advanced by Bates et al. (2000) in their Analytical Narrative Project. In other words, the divergence from the ideal-type to the individual case is the "payoff" (Swedberg, 2018: 8-9): where the researcher can then hypothesise how and why it diverged from the ideal-type. Therefore, viewing rationality in ideal-typical terms "prevent[s] logically general abstractions from being mistaken for either reliable predictions or transcendental certainties" (Jackson, 2017: 80) such as the way it is frequently understood in orthodox terrorism studies, while it overcomes a particularist approach.

I have, so far, argued that (a) proving that terrorism is rational is relevant to CTS; that (b) the ways in which rationality has been conceptualised in terrorism studies are not fertile enough for CTS to do so; and that (c) an ideal-typical approach can resolve the tension between adopting a reflexivist stance and making knowledge claims on rationality. Of course, this claim per se does not ineluctably lead to the conclusion that among all possible ideal-types of rationality, CTS should incorporate the Weberian one. In the coming section, I aim to explain why.

\section{The Case for a neo-Weberian Approach}

If there is a "division of labour" through which some authors concentrate on creating idealtypes and others attempt to confront them with particular cases (as Jackson [2010: 152] has argued), 
then CTS should adopt Weber's typification of rationality since few social theorists have attained the level of sophistication that he accomplished in his categorisation of rationality (see, e.g., Levine, 1981: 10). As I will explain in the coming paragraphs, Weber conceptualised rationality both as a driver of action and as a process. In addition, Jackson et al. (2009: 234) have pointed out when they framed the "new research agenda" for CTS that a key challenge was "the risk of bifurcating the broader terrorism studies field into critical and orthodox intellectual ghettos [that] would likely result in a level of intellectual and political irrelevance." If we were to follow Jackson in advocating in favour of an inter-paradigmatic dialogue, then, I suggest, it is essential to share part of our canon. Weber's work on rationality set an idea of rationalisation that fostered part of the work of the Frankfurt School, but also the foundations of RCT. I suggest that, beyond this sophistication, a pragmatic reason to invoke Weber is to use his ideas as a lingua franca between competing approaches to terrorism studies.

However, it is important to highlight the fact that Weber used the concept of rationality in several ways throughout his oeuvre. Similar to what, for instance, Załęski (2010) did by reconstructing and completing Weber's ideal-types for the study of religion, drawing on the work of Kalberg (1980) and Levine (1981), I will attempt to clarify Weber's understanding of rationality. It is essential to bear in mind that the purpose of an ideal-type is to be useful (Jackson, 2010: 135); therefore, we can, and indeed must, rectify them by making them more systematic, if this adaptation us to use these idealtypes in a more insightful way. Before I proceed with this re-ideal-typification, I must highlight that the debate on what Weber means by rationality is still an ongoing one, and the purpose of this paper is in no way to provide a final solution to it. Instead, it will attempt to sketch which kind of insights this ideal-typification of rationality could bring to the discipline. Before continuing, as a preliminary note, let us keep in mind that Weber conceptualised the manifestation of rationality in two varieties: subjective, as a driver of social action, and objective (or, better said, objectified), which corresponds with institutionalised processes of rationalisation (Levine, 1981: 10). This considered, let us turn to these categories.

In Economy and Society (1978 [1922]: 4), Weber described Sociology as the "science concerning itself with the interpretive understanding of social action and thereby with a causal explanation of its course and consequences." This stemmed from his Verstehen, the idea that sociologists must grasp the meaning of social action from the social actor's perspective, for what the sociologist, therefore, had to empathise to understand what motivated a determined social action. Its scope is different from the one of psychology, as it is interested in the motivation of social relationships of action (Weber, 1981 [1913]: 152), intentionally directed towards social “others". Thus, Weber proposed a classification of social action in relation to four orientations: instrumental rationality, value 
rationality, affect, and tradition (Table 1). Following Kant's dichotomy between means and ends (Swedberg and Agevall, 2016: 166), Weber argued that an action is instrumentally rational (Zweckrational) when it aims towards the realisation of a determined end (Zweck) through a "conscious and calculated use of certain means" (Swedberg and Agevall, 2016: 166). By the same token, an action is value-rational (Wertrational) when the social actor "feels forced or compelled to act in this manner, [...] regardless of [...] the cost to the actor" (Swedberg and Agevall, 2016: 166) and “independently of its prospects of success" (Weber, 1978 [1922]: 25). In contrast, non-rational social action is driven either by interiorised habits (traditional) or by the actor's emotions (affective) (this interest, should be noted, would roughly correspond to the research of sociologist Jon Elster who, drawing on Weber, has suggested that motivations go beyond pure unbounded selfish calculations [see, e.g., Elster, 2009]). It is important to highlight that ideal-types do not exist in the real world, yet they are valuable in virtue of their results - they provide us with interesting insights by contrasting them with empirics (Weber, 1978 [1922]: 26).

Table 1. Orientations of social action (Weber, 1978 [1922]: 4)

\begin{tabular}{|c|c|}
\hline Rational orientation & Non-rational orientation \\
\hline Value Rational & Affective \\
\hline Instrumentally rational & Traditional \\
\hline
\end{tabular}

Source: Author.

The above-mentioned typology (see Table 1) is similar to the one that Tosini (2009; 2010) suggested to utilise in order to understand suicide terrorism. Analysing interviews and biographical information of suicide terrorists, he follows Weber's typology of social action, arguing that suicide terrorism can be rational in both senses (as instrumental and value-oriented), and non-rational in the instances where it is caused by “outrage and humiliation" (Tosini, 2010: 412). Therefore, terrorists can be value rational in that they are motivated by political and religious "interiorised [...] moral criteria that command certain actions regardless of their consequences" (Tosini, 2010: 408) as well as instrumentally rational since it provides "prestige [...] to his name and his family" (Ricolfi, 2006: 113). This typification of rationalities is not a description of the world; rather, it more of an analytical tool that CTS may apply to see contrasts or similarities, and then tell a useful story as Tosini does.

In contrast, objectified rationality corresponds to processes of "rationalizations [...] in all areas of culture" (Weber, 2013 [1905]: xxxix) that are transformed towards an "ultimate points of view" (Levine, 1981: 12). Terrorism could, therefore, be considered a "rationalising” force insofar 
as it attempts to put in place a determined point of view (religious in the case of Islamic terrorism, nationalistic in the case of secessionism, etc.) in different spheres of life such as economic organisation, political order, military structures, legal systems, education and certainly, religion, inter alia.

Levine (1981: 11-15) has argued that these processes of objectified institutional rationalisations can be ideal-typified in four primary forms: (1) instrumental (practical in Kalberg, 1980), (2) substantive, (3) formal, and (4) conceptual (theoretical in Kalberg, 1980). Instrumental objectified rationality occurs when spheres of life become "increasingly more precise in calculating the methodical attainment of given practical ends" (Weber, 1946 [1922]: 293), while substantive rationality, "accords predominance to ethical imperatives [...] or political maxims" (Levine, 1981: 13). Scilicet, they represent the institutionalisation of the instrumental and valueoriented subjective rationalities (respectively). Further, formal rationality manifests an "inexorable" process of bureaucratisation (Weisz, 2014: 693-4), in which rules and routines (Planmässigkeit) are set to limit the effects of social relations in favour of efficiency and predictability (Levine, 1981: 13) while, lastly, conceptual rationality relates to the constitution of a worldview and the establishment of a canon (Levine, 1981: 12) composed of "symbolic meanings" (Kalberg, 1980: 1152).

There are numerous cases in which terrorism has crystallised in the form of institutions, for instance, the case of the LTTE in Sri Lanka, or ISIS in Syria and Iraq. It can be argued that these terrorist groups engage in processes of rationalisation that transform the social world of their societies. In the case of the latter, the establishment of a certain worldview (see Juergensmeyer, 2018), the systematic use of their propaganda and housing programmes (Gerges, 2017: 178) or the recently revealed bureaucratic structure (see Callimachi, 2018) can all be understood as part of a rationalising process in which terrorism attempts to control all spheres of life, subjugating them under "ultimate points of view" (see Table 2). Further research in the form of rigorous case studies could confront these ideal-types with the evidence, potentially leading to interesting insights on how terrorist organisations engage in processes of modern rationalisation. 
Table 2: Levine's typology of Weberian objectified rationalities (Levine's, 1981: 13), applied to ISIS

\begin{tabular}{|c|c|c|}
\hline \multirow{2}{*}{$\begin{array}{c}\text { Form of objectified } \\
\text { rationality }\end{array}$} & \multicolumn{2}{|c|}{ Institutional Spheres } \\
\hline & Religion & Economy \\
\hline Conceptual & $\begin{array}{l}\text { Establishment of a worldview } \\
\text { in al Abu Bakr al-Baghdadi’s } \\
\text { theology (Juergensmeyer, } \\
\text { 2018) }\end{array}$ & $\begin{array}{l}\text { Science of economics (Levine, } \\
\text { 1981) e.g. applied to } \\
\text { agriculture (see Jaafara and } \\
\text { Woertz, 2016) }\end{array}$ \\
\hline Instrumental & Use of prayers (Levine, 1981) & $\begin{array}{c}\text { Systematic use of propaganda } \\
\text { such as Dabiq (see Mahood } \\
\text { and Rane, 2017) }\end{array}$ \\
\hline Substantive & $\begin{array}{l}\text { Jihad as the greatest deed in } \\
\text { islam (Roy, 2017: 13) as a } \\
\text { doctrine for salvation }\end{array}$ & $\begin{array}{l}\text { Allocation of resources } \\
\text { according to a standard of } \\
\text { fairness (Levine, 1981); e.g. } \\
\text { housing programmes for } \\
\text { homeless ISIS fighters } \\
\text { (Gerges, 2017: 178) }\end{array}$ \\
\hline Formal & $\begin{array}{c}\text { Sharia Law; Establishment of } \\
\text { praying routines }\end{array}$ & $\begin{array}{c}\text { Bureaucratisation and tax } \\
\text { accounting (Callimachi, 2018) }\end{array}$ \\
\hline
\end{tabular}

Source: Author

It should be noted that this framework does not, and indeed should not, be applied exclusively to the study of "terrorists" groups in CTS. Applying these ideal-types to hegemonic worldviews such as the "War on Terror", in order to construct insightful narratives, can potentially show the ways in which this phenomenon is conceptually rationalised through a determined scholarship (i.e. problem-solving orthodox scholarship); instrumentally rationalised through the construction of a "useful enemy" (Keen, 2014: 171) which, in turn, legitimises a governmental logic (Aradau and Van Munster, 2007) or a dominant class project (Boukalas, 2015). Further, we could argue that the War on Terror is substantively rationalised in a language of "good versus evil" (see Richards, 2017), and 
formally rationalisated through the bureaucratisation of violence expressed in "efficient" targeted killings (see Adams and Barrie, 2013).

\section{Conclusion}

The question of rationality has been largely disregarded in CTS. This paper has argued why rationality should be at the heart of CTS, and how a Weberian ideal-typical approach offers a "via media" between positivist and particularist research programmes. The major limitation of this piece is the fact that these ideal-types must be applied in rigorous case studies in order to obtain interesting findings. Therefore, to this end, further work needs to be undertaken to apply and refine these typifications. These limitations notwithstanding, this paper has contributed to the ways in which one can understand rationality in CTS, insofar as it offers a way forward to make knowledge claims while recognising the "ontological instability" of the object studied. This is an approach that assists CTS overcome the politics of "anti-knowledge", creating new possibilities for analytical narratives on the ways in which terrorists are rational, and in the ways whereby terrorism is rationalised in formal (e.g. state terrorism) and informal institutions.

Contra the "sciences" of his time, Weber rejected the notion that "rationality derived from the Enlightenment" (Kalberg, 1980: 1160), as well as its supposed singularity as a "uniquely Western phenomenon." (Levine, 1981: 9). Perhaps his ideas can illuminate contemporary debates in International Relations and Security Studies, helping us challenge contemporary assumptions by understanding the ways in which terrorism is rationally motivated-regardless of how morally reprehensible these actions might be.

\section{References}

Adams, Richard and Chris Barrie (2013): 'The bureaucratization of War: Moral Challenges Exemplified by the Covert Lethal Drone', Ethics \& Global Politics 6(4): pp. 245-260. DOI: https://doi.org/10.3402/egp.v6i4.21850

Agamben, Giorgio (2005): State of Exception (Vol 2). Chicago: University of Chicago Press.

Alker, Hayward R, Jr. (1990): 'Rescuing "Reason" from the "Rationalists": Reading Vico, Marx and Weber as Reflective Institutionalists', Millennium 19(2): pp. 161-184. DOI: https://doi.org/10.1177/03058298900190020401

Aradau, Claudia and Rens van Munster (2007): 'Governing Terrorism Through Risk: Taking Precautions, (un)Knowing the Future', European Journal of International Relations 13(1): pp. 89115. DOI: https://doi.org/10.1177/1354066107074290 
Bates, Robert et al., (2000): 'The Analytical Narrative Project', American Political Science Review 94(3): pp. 696-702. DOI: https://doi.org/10.2307/2585843

Boukalas, Christos (2015): 'Class war-on-terror: counterterrorism, accumulation, crisis', Critical Studies on Terrorism 8(1): pp. 55-71. DOI: https://doi.org/10.1080/17539153.2015.1005932

Butler, Judith (2006): Precarious Life: The Powers of Mourning and Violence. London: Verso.

Callimachi, Rukmini (2018): 'The Isis Files'. The New York Times. 4 April. Accessible at: https://www.nytimes.com/interactive/2018/04/04/world/middleeast/isis-documents-mosuliraq.html (1 April 2019)

Caplan, Bryan (2006): 'Terrorism: The Relevance of the Rational Choice Model', Public Choice 128(1-2): pp. 91-07. DOI: https://doi.org/10.1007/s11127-006-9046-8

Cox, Robert W. (1981): 'Social Forces, States and World Orders: Beyond International Relations Theory', Millennium: Journal of International Studies 10(2): pp. 126-155. DOI: https://doi.org/10.1177/03058298810100020501

Dillet, Benoit (2017): ‘What is poststructuralism?’ Political Studies Review 15(4): pp. 516-527. DOI: https://doi.org/10.1177/1478929917712931

Elster, Jon (2009): Strong Feelings: Emotion, Addiction, and Human Behavior. Cambridge: MIT Press.

Fitzgerald, James (2016): 'Critical epistemologies of terrorism', in Richard Jackson (ed.) Routledge Handbook of Critical Terrorism Studies. London: Routledge. pp. 65-75.

Foucault, Michel (1983): Beyond Structuralism and Hermeneutics. Chicago: Chicago University Press.

Gambetta, Diego (2005): Making Sense of Suicide Missions. Oxford: Oxford University Press. DOI: https://doi.org/10.1093/acprof:oso/9780199276998.001.0001

Gentry, Caron and Laura Sjoberg (2016): 'Female Terrorism and Militancy', in Richard Jackson (ed.) Routledge Handbook of Critical Terrorism Studies. London: Routledge. pp. 65-75.

Gerges, Fawaz A. (2017): Isis: A History. Princeton: Princeton University Press.

Gerhardt, Uta (1994): 'The Use of Weberian Ideal-Type Methodology in Qualitative Data Interpretation: an Outline for Ideal-Type Analysis', Bulletin of Sociological Methodology/Bulletin de Méthodologie Sociologique 45(1): pp. 74-126. DOI: https://doi.org/10.1177/075910639404500105

Gunning, Jeroen (2009): 'Social Movement Theory and the Study of Terrorism', in Richard Jackson, Marie B. Smyth and Jeroen Gunning (eds.) Critical Terrorism Studies: A New Research Agenda. London: Routledge. pp. 156-177. 
Jaafara, Hadi H. and Eckart Woertz (2016): 'Agriculture as a funding source of ISIS: A GIS and remote sensing analysis', Food Policy 64: pp. 14-25. DOI: https://doi.org/10.1016/j.foodpol.2016.09.002

Jackson, Patrick Thaddeus (2010): The Conduct of Inquiry in International Relations: Philosophy of Science and its Implications for the Study of World Politics. New York: Routledge. DOI: https://doi.org/10.4324/9780203843321

Jackson, Patrick Thaddeus (2017): 'The Production of Facts: Ideal-Typification and the Preservation of Politics', in Richard Ned Lebow (ed.) Max Weber and International Relations. Cambridge: Cambridge University Press. pp. 79-96. DOI: https://doi.org/10.1017/9781108236461.004

Jackson, Richard (2008): 'An Argument for Terrorism', Perspectives on Terrorism 2(2): pp. 25-32. Accessible at: http://www.terrorismanalysts.com/pt/index.php/pot/article/view/27/html (1 April 2019).

Jackson, Richard et al. (2009): 'Critical terrorism studies: framing a new research agenda', in Richard Jackson, Marie B. Smyth and Jeroen Gunning (eds.) Critical Terrorism Studies: A New Research Agenda. London: Routledge. pp. 156-177. DOI: https://doi.org/10.4324/9780203880227

Jarvis, Lee (2016): 'Critical terrorism studies after 9/11', in Richard Jackson (ed.) Routledge Handbook of Critical Terrorism Studies. London: Routledge. pp. 44-54.

Juergensmeyer, Mark (2018): 'Thinking Sociologically about Religion and Violence: The Case of ISIS', Sociology of Religion 79(1): pp. 20-34. DOI: https://doi.org/10.1093/socrel/srx055

Kalberg, Stephen (1980): 'Max Weber's types of rationality: Cornerstones for the analysis of rationalization processes in history', American Journal of Sociology 85: 1145-1179. DOI: https://doi.org/10.1086/227128

Kalyvas, Stathis and Ignacio Sánchez-Cuenca (2005): 'Killing Without Dying: the Absence of Suicide Missions', in Diego Gambetta (ed.) Making Sense of Suicide Missions. Oxford: Oxford University Press. pp. 209-232. DOI: https://doi.org/10.1093/acprof:oso/9780199276998.003.0006

Keen, David (2014): Useful Enemies: When Waging Wars is More Important than Winning Them. Yale: Yale University Press.

Keohane, Robert (1988): 'International Institutions: Two Approaches', International Studies Quarterly 32(4); 379-396. DOI: https:// doi.org/10.2307/2600589

King, Gary, et al. (1994): Designing Social Inquiry: Scientific Inference in Qualitative Research. Princeton: Princeton University Press. DOI: https://doi.org/10.1515/9781400821211

Lebow, Richard Ned (Ed.) (2017): Max Weber and International Relations. Cambridge: Cambridge University Press. DOI: https://doi.org/10.1017/9781108236461 
Levine, Donald N. (1981): 'Rationality and Freedom: Weber and Beyond', Sociological Inquiry 51(1): pp.5-25. DOI: https://doi.org/10.1111/j.1475-682X.1981.tb01021.x

Mahood, Samantha and Halim Rane (2017): 'Islamist narratives in ISIS recruitment propaganda', The Journal of International Communication 23(1): pp. 15-35. DOI: https://doi.org/10.1080/13216597.2016.1263231

Mann, Michael (2005): Incoherent Empire. London: Verso.

McKeown, Timothy (1999): 'Case Studies and the Statistical Worldview: Review of King, Keohane, and Verba's Designing Social Inquiry: Scientific Inference in Qualitative Research', International Organization 53(1): pp. 161-190. DOI: https://doi.org/10.1162/002081899550841

Pape, Robert A. (2003): 'The Strategic Logic of Suicide Terrorism', American Political Science Review 97(3): pp. 343-361. DOI: https://doi.org/10.1017/S000305540300073X

Pape, Robert A. (2006): Dying to win: The strategic logic of suicide terrorism. New York: Random House Incorporated.

Perry, Simon and Badi Hasisi (2015): 'Rational Choice Rewards and the Jihadist Suicide Bomber', Terrorism and Political Violence 27(1): pp. 53-80. DOI: https://doi.org/10.1080/09546553.2014.962991

Richards, Imogen (2017): “Good and Evil” narratives in Islamic State media and Western government statements, Critical Studies on Terrorism 10(3): pp. 404-428. DOI: https://doi.org/10.1080/17539153.2017.1311495

Ricolfi, Luca (2006): 'Palestinians, 1981-2003', in Gambetta, Diego (ed.) Making Sense of Suicide Missions. Oxford: Oxford University Press. pp. 77-130. DOI: https://doi.org/10.1093/acprof:oso/9780199276998.003.0003

Roy, Olivier (2017): Jihad and death: The global appeal of Islamic State. Oxford: Oxford University Press.

Smith, Steve (2002): 'Historical Sociology and International Relations Theory', in Stephen Hobden and John M. Hobson (eds.) Historical Sociology of International Relations. Cambridge: Cambridge University Press. pp. 223-243.

Stampnitzky, Lisa (2013): Disciplining Terror: How Experts Invented 'Terrorism'. Cambridge: Cambridge University Press. DOI: https://doi.org/10.1017/CBO9781139208161

Stump, Jacob L. (2016): 'Methodology and the critical study of terrorism', in Richard Jackson (ed.) Routledge Handbook of Critical Terrorism Studies. London: Routledge. pp 106-116. 
Swedberg, Richard (2018): 'How to use Max Weber's ideal type in sociological analysis', Journal of Classical Sociology 18(3): pp. 181-196. DOI: https://doi.org/10.1177\%2F1468795X17743643

Swedberg, Richard and Ola Agevall (2016): The Max Weber dictionary: key words and central concepts. Stanford: Stanford University Press.

Tellidis Ioannis and Harmonie Toros (eds.) (2015): Researching Terrorism, Peace and Conflict Studies: Interaction, Synthesis and Opposition. London: Routledge. DOI: https://doi.org/10.4324/9781315778914

Tellidis, Ioannis (2016) 'Terrorism and Peace Studies', in Richard Jackson (ed.) Routledge Handbook of Critical Terrorism Studies. London: Routledge. pp 626-650.

Tosini, Domenico (2009): 'A Sociological Understanding of Suicide Attacks', Theory, Culture \& Society 26(4): pp. 67-96. DOI: https://doi.org/10.1177/0263276409104969

Tosini, Domenico (2010): 'Calculated, passionate, pious extremism: Beyond a rational choice theory of suicide terrorism', Asian Journal of Social Science 38(3): pp. 394-415. DOI: https://doi.org/10.1163/156853110X499945

Weber, Max (1946 [1922]): 'The social psychology of the world religions', in Gerth Hans and Charles Wright Mills (eds.) From Max Weber. New York: Oxford University Press.

Weber, Max (1978 [1922]). Economy and Society: An outline of interpretive sociology. University of California Press.

Weber, Max (1981 [1913]): 'Some Categories of Interpretive Sociology', The Sociological Quarterly 22(2): pp. 151-180. DOI: https://doi.org/10.1111/j.1533-8525.1981.tb00654.x

Weber, Max (2013 [1905]): The Protestant Ethic and the Spirit of Capitalism. London: Routledge.

Weisz, Eduardo (2014): 'Nación y racionalización: dos focos en tensión en los escritos políticos de Max Weber', Estudios Sociológicos XXXII(96): pp. 681-708. Accessible at: http://www.redalyc.org/pdf/598/59840009009.pdf (1 April 2019)

Wolfendale, Jessica (2016): 'The Narrative of Terrorism as an Existential Threat', in Richard Jackson (ed.) Routledge Handbook of Critical Terrorism Studies. London: Routledge. pp. 44-54.

Załęski, Pawel (2010): 'Ideal-types in Max Weber's Sociology of Religion: Some Theoretical Inspirations for a Study of the Religious Field', Polish Sociological Review 171(3): pp. 319-325. Accessible at: https://www.jstor.org/stable/41275160 (1 April 2019) 